\title{
Understanding side-effects of anti-CGRP and anti-CGRP receptor antibodies
}

\author{
Kristian Agmund Haanes ${ }^{1 *}$, Lars Edvinsson ${ }^{1,2}$ and Anette Sams ${ }^{1}$
}

Keywords: CGRP, GLP-1, Side effects, Constipation, Monoclonal antibodies

To the editor.

Therapeutic prevention and intervention of migraine attacks with the novel monoclonal antibodies (mAbs) against Calcitonin Gene-Related Peptide (CGRP) or the CGRPreceptor (hereafter named jointly "anti-CGRP therapy") are currently being initiated in thousands of patients.

Although the clinical trials on anti-CGRP therapy have reported surprising limited number of side-effects considering CGRPs abundance [1], the most up to date (31th of December 2019) data from the FDA Adverse Event Reporting System, show that 4082 of the total reported side-effects $(24,573)$ to date were related to gastrointestinal disorders (17\%). Generally, constipation is a significant anti-CGRP side-effect reported in 3-4\% of patients [2]. These effects might be exacerbated when patients are using other medications that also affect the gastrointestinal system, such as anti-depressants and morphine receptor activating drugs.

Reviewing the current literature on the importance of CGRP in the gastrointestinal system, it appears that CGRP per se may reduce gastric emptying $[3,4]$, abrogate contractions in rat colon [5] and reduce food intake [6, 7]. Some of these effects were indirect via neuronal CGRP-receptors [3] and others were local [5]. This letter aims to raise the awareness of an important gastrointestinal target for CGRP which could explain anti-CGRP therapy induced constipation and potentially suggest a pharmacological intervention to relieve symptoms for patients that are suffering from constipation.

\footnotetext{
* Correspondence: kristian.agmund.haanes@regionh.dk

${ }^{1}$ Department of Clinical Experimental Research, Copenhagen University Hospital, Glostrup, Denmark

Full list of author information is available at the end of the article
}

Sams and coworkers have shown that a long-acting CGRP peptide analogue significantly increased levels of circulating Glucagon-Like Peptide-1 (GLP-1) by $>60 \%$ [6]. Associated studies in a murine enteroendocrine Lcell line [6] and on perfused ileum [8] supported the direct and specific concentration-dependent CGRP-induced GLP-1 secretion [6]. Thus, since CGRP induces local GLP-1 secretion in the gastrointestinal tract, reduced levels of GLP-1 could be associated with anti-CGRP therapy. The regulation might be bidirectional since GLP-1 has been shown to induce secretion of enteric nerve CGRP in mouse colon and via modulation of epithelial salt conductance, this has been suggested as a mechanism of GLP-1 drug induced diarrhea [9].

Since the above studies collectively show that gastrointestinal side-effects are most likely indirect, they could therefore be treated without interfering with the clinical effect of blocking the CGRP signaling system. In addition, these data provide important insight to the effects of CGRP in the gastrointestinal system, and we recommend that GLP-1 and GLP-1 metabolite levels should be investigated clinically in patients on the antiCGRP or CGRP-receptor mAbs. Such investigation is highly relevant in the light of the importance of GLP-1 in long term glucose homeostasis, regulation of foodintake and gastric motility [10] and could provide further insight to conclude whether GLP-1 supplementation would be beneficial in a subgroup of patients suffering from migraine-therapy associated constipation.

\footnotetext{
Abbreviations

CGRP: Calcitonin Gene-Related Peptide; mAbs: Monoclonal antibodies; GLP1: Glucagon-Like Peptide-1
}

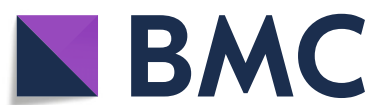

(c) The Author(s). 2020 Open Access This article is licensed under a Creative Commons Attribution 4.0 International License, which permits use, sharing, adaptation, distribution and reproduction in any medium or format, as long as you give appropriate credit to the original author(s) and the source, provide a link to the Creative Commons licence, and indicate if changes were made. The images or other third party material in this article are included in the article's Creative Commons licence, unless indicated otherwise in a credit line to the material. If material is not included in the article's Creative Commons licence and your intended use is not permitted by statutory regulation or exceeds the permitted use, you will need to obtain permission directly from the copyright holder. To view a copy of this licence, visit http://creativecommons.org/licenses/by/4.0/ The Creative Commons Public Domain Dedication waiver (http://creativecommons.org/publicdomain/zero/1.0/) applies to the data made available in this article, unless otherwise stated in a credit line to the data. 


\section{Acknowledgements}

Non applies.

\section{Authors' contributions}

All authors contributed equally. The authors read and approved the final manuscript.

\section{Funding}

Not applicable.

\section{Availability of data and materials}

Not applicable.

\section{Ethics approval and consent to participate}

Not applicable.

\section{Consent for publication}

Not applicable.

\section{Competing interests}

Kristian Agmund Haanes has given lectures on CGRP for Teva. Lars Edvinsson has given lectures on CGRP for Amgen, Novartis, and Teva, and has received minor grant support, though none pertaining to the current commentary. Anette Sams is a previous employee at Novo Nordisk, but with no current conflict of interest.

\section{Author details}

'Department of Clinical Experimental Research, Copenhagen University Hospital, Glostrup, Denmark. ${ }^{2}$ Department of Clinical Sciences, Division of Experimental Vascular Research, Lund University, Lund, Sweden.

Received: 4 March 2020 Accepted: 11 March 2020

Published online: 16 March 2020

\section{References}

1. Russell FA, King R, Smillie SJ et al (2014) Calcitonin gene-related peptide: physiology and pathophysiology. Physiol Rev 94:1099-1142

2. Charles A, Pozo-Rosich P (2019) Targeting calcitonin gene-related peptide: a new era in migraine therapy. Lancet 394:1765-1774

3. Jurgen LH (1988) Calcitonin and CGRP inhibit gastrointestinal transit via distinct neuronal pathways. Am J Phys 254:G920-G924

4. L'Heureux MC, St-Pierre S, Trudel L et al (2000) Digestive motor effects and vascular actions of CGRP in dog are expressed by different receptor subtypes. Peptides 21:425-430

5. Clifton MS, Hoy JJ, Chang J et al (2007) Role of calcitonin receptor-like receptor in colonic motility and inflammation. Am J Physiol Gastrointest Liver Physiol 293:G36-G44

6. Nilsson C, Hansen TK, Rosenquist C et al (2016) Long acting analogue of the calcitonin gene-related peptide induces positive metabolic effects and secretion of the glucagon-like peptide-1. Eur J Pharmacol 773:24-31

7. Sanford D, Luong L, Gabalski A et al (2019) An Intraperitoneal treatment with calcitonin gene-related peptide (CGRP) regulates appetite, energy intake/expenditure, and metabolism. J Mol Neurosci 67:28-37

8. Herrmann-Rinke C, McGregor GP, Goke B (2000) Calcitonin gene-related peptide potently stimulates glucagon-like peptide-1 release in the isolated perfused rat ileum. Peptides 21:431-437

9. Handelsman Y, Wyne K, Cannon A et al (2018) Glycemic efficacy, weight effects, and safety of once-weekly glucagon-like Peptide-1 receptor agonists. J Manag Care Spec Pharm 24:S14-S29

10. Flint A, Raben A, Ersboll AK et al (2001) The effect of physiological levels of glucagon-like peptide-1 on appetite, gastric emptying, energy and substrate metabolism in obesity. Int J Obes Relat Metab Disord 25:781-792

\section{Publisher's Note}

Springer Nature remains neutral with regard to jurisdictional claims in published maps and institutional affiliations.

\section{Ready to submit your research? Choose BMC and benefit from:}

- fast, convenient online submission

- thorough peer review by experienced researchers in your field

- rapid publication on acceptance

- support for research data, including large and complex data types

- gold Open Access which fosters wider collaboration and increased citations

- maximum visibility for your research: over $100 \mathrm{M}$ website views per year

At BMC, research is always in progress.

Learn more biomedcentral.com/submissions 